\title{
Bivalirudin anticoagulation for cardiopulmonary bypass in a patient with heparin-induced throm- bocytopenia
}

\author{
[L'anticoagulation avec la bivalirudine pour la circulation extracorporelle chez
}

un patient atteint de thrombocytopénie immunitaire à l'héparine (TIH)]

Marcin Wasowicz MD, ${ }^{*}$ Annette Vegas MD FRCPC, ${ }^{*}$ Michael A. Borger MD FRCSC, $†$ Stephen Harwood CCP CPC $\ddagger$

Purpose: To describe the perioperative management in a heparin-induced thrombocytopenia (HIT) positive patient who had prosthetic valve endocarditis and an aortic root abscess. The patient underwent high-risk cardiac re-operation with the use of the alternative anticoagulant, bivalirudin.

Clinical features: A 62-yr-old patient who underwent stentless tissue aortic valve replacement with a Toronto-SPV valve in 1998, was admitted to hospital with symptoms of stroke. A heparin infusion was started and further investigation revealed positive blood cultures. The patient developed HIT which was confirmed by laboratory tests. Echocardiographic examination performed one month later showed vegetations on the aortic tissue valve and a small aortic root abscess. The patient still tested positively for the presence of HIT antibodies and was treated conservatively with antibiotics. A repeat echocardiographic examination showed progression of the aortic root abscess and it was decided to proceed with urgent redo aortic valve surgery. Anticoagulation for cardiopulmonary bypass (CPB) was achieved with the use of a direct thrombin inhibitor (DTI), bivalirudin. Following an uneventful wean from CPB, hemostasis was achieved within $40 \mathrm{~min}$. The postoperative course was uncomplicated and the patient was discharged from hospital on the seventh postoperative day.

Conclusion: Bivalirudin is a DTI, which can be used as an alternative anticoagulant for CPB in HIT positive patients. This case report showed a favourable outcome with bivalirudin for urgent complex redo cardiac surgery requiring $\mathrm{CPB}$.
Objectif : Décrire la prise en charge périopératoire d'un patient atteint de $\mathrm{TIH}$, victime d'une endocardite sur prothèse valvulaire et d'un abcès à la racine de l'aorte. Le patient a subi une réopération cardiaque à haut risque avec l'usage d'anticoagulant de remplacement, la bivalirudine.

Éléments cliniques : Un patient de 62 ans chez qui on a remplacé le tissu de la valve aortique, sans endoprothèse, par une valve Toronto-SPV en 1998 a été admis à l'hôpital pour des symptômes d'accident vasculaire cérébral. Une perfusion d'héparine a été amorcée et un examen ultérieur a révélé des cultures sanguines positives. Une TIH s'est développée et a été confirmée par les tests de laboratoire. L'échocardiographie, réalisée un mois plus tard, a montré des végétations sur la valve tissulaire aortique et un petit abcès à la racine de l'aorte. Les résultats aux tests indiquant toujours la présence d'anticorps de $\mathrm{TIH}$, le patient a reçu une antibiothérapie conservatrice. Une nouvelle échocardiographie a montré la progression de l'abcès aortique, ce qui a conduit à répéter d'urgence l'opération de la valve aortique. L'anticoagulation pour la circulation extracorporelle (CEC) a été réalisée avec un inhibiteur direct de la thrombine (IDT), la bivalirudine. Après un sevrage sans incident de la CEC, l'hémostase a été atteinte en moins de 40 min. Aucune complication n'est survenue par la suite et le patient a quitté l'hôpital au septième jour postopératoire.

Conclusion: La bivalirudine est un IDT qui peut être utilisé comme anticoagulant de remplacement pendant la CEC chez des patients victimes de $\mathrm{TIH}$.

From the Department of Anesthesia and Pain Management, ${ }^{*}$ Division of Cardiac Surgery, $†$ and Cardiovascular Perfusion Services, $\ddagger$ Toronto General Hospital, University of Toronto, Toronto, Ontario, Canada. Address correspondence to: Dr. Annette Vegas, Department of Anesthesia, Toronto General Hospital, 200 Elizabeth St., 3 EN-406,

Toronto, Ontario M5G 2C4, Canada. Phone: 416-340-4800, ext. 6443; Fax: 416-340-3698; E-mail: annette.vegas@uhn.on.ca Accepted for publication May 31, 2005. Revision accepted July 5, 2005. 
$\mathrm{H}$ EPARIN induced thrombocytopenia (HIT) is an adverse drug reaction to heparin characterized by thrombocytopethrombosis. It is caused by heparin-dependent, plateletactivating antibodies that recognize a complex of heparin bound to platelet factor 4 (PF4). ${ }^{1}$ Heparin induced thrombocytopenia can be a life threatening condition if cardiac surgery is planned. ${ }^{1,2}$ Anticoagulation during cardiopulmonary bypass $(\mathrm{CPB})$ requires a fast-acting anticoagulant, which can be monitored easily and has an effective antidote to restore coagulation after $\mathrm{CPB}$. Heparin is the gold-standard anticoagulant for $\mathrm{CPB}$ but must be substituted in HIT-positive patients. Currently, there are few alternative anticoagulants for $\mathrm{CPB}$. Variable pharmacokinetics, monitoring limitations and lack of reversibility restrict the choice of anticoagulants. The intravenously administered direct thrombin inhibitor (DTI) bivalirudin, a semi-synthetic hirudin analogue, undergoes proteolytic degradation and has a short half-life $(25 \mathrm{~min}){ }^{3}$ Bivalirudin is approved for percutaneous coronary intervention and management of acute coronary syndromes. ${ }^{3}$ There are several reports describing the off-label use of bivalirudin during cardiac surgery, ${ }^{4-6}$ but nearly all of these reports were in low risk patients. We report the use of bivalirudin for complex cardiac re-operation in a HIT-positive patient who developed prosthetic valve endocarditis and an aortic root abscess.

\section{Case presentation}

This report was prepared with patient consent according to institutional guidelines.

A 62-yr-old male patient who underwent stentless tissue aortic valve replacement surgery (TorontoSPV valve) in 1998 was admitted to hospital with symptoms of stroke. A magnetic resonance imaging exam showed bilateral pontine infarctions due to basilar artery thrombosis and a heparin infusion was started. The patient also had positive blood cultures (Cardiobacterium homminis) without echocardiographic features of bacterial endocarditis. Therapy with antibiotics was started. After ten days of heparin therapy the patient developed thrombocytopenia. An initial screening test for antibodies against PF4/ unfractionated heparin complexes (ELISA) and a subsequent serotonin release assay (SRA) were positive for HIT. Heparin therapy was discontinued and no other anticoagulant was administered.

After one month of antibiotic therapy the patient had follow-up transesophageal echocardiography (TEE) that showed an aortic root abscess, small prosthetic valve vegetations, and mild aortic insuf- ficiency. The SRA test remained positive, and it was decided to continue antibiotic therapy and wait until the HIT-antibody test became negative. A repeat TEE performed two weeks later revealed the aortic root abscess had doubled in size, from 0.7 to $1.4 \mathrm{~cm}$. A decision was made to proceed with urgent redo aortic valve surgery with the use of bivalirudin. Preoperative coronary angiography, without anticoagulants or antiplatelet drugs, showed critical arterial stenosis of the first obtuse marginal branch.

Preoperative laboratory investigation included hemoglobin $149 \mathrm{~g} \cdot \mathrm{L}^{-1}$, platelet count $281 \times 10^{9} \cdot \mathrm{L}^{-1}$, prothrombin time $=13.8 \mathrm{sec}, \mathrm{INR}=1.02$ and normal liver and kidney function. The patient received a heparin free perioperative course including no heparin in flush bags and a heparin uncoated Swan-ganz catheter and $\mathrm{CPB}$ circuit. Anesthesia was induced with propofol $100 \mathrm{mg} i v$, midazolam $2 \mathrm{mg} i v$, fentanyl $0.5 \mathrm{mg}$ iv and pancuronium bromide $10 \mathrm{mg} i \mathrm{v}$. Anesthesia was maintained with isoflurane (1.2-1.5 MAC), intermittent $i v$ fentanyl (total $0.5 \mathrm{mg}$ ), and an $i v$ infusion of propofol $\left(80 \mu \mathrm{g} \cdot \mathrm{kg}^{-1} \cdot \mathrm{hr}^{-1}\right)$ during and after CPB. To minimize post-bypass bleeding, aprotinin $(4,000,000$ KIU) was administered as a 2,000,000 KIU bolus in the $\mathrm{CPB}$ circuit prime followed by an iv infusion $250,000 \mathrm{KIU} \cdot \mathrm{hr}^{-1}(2,000,000 \mathrm{KIU})$ during and after $\mathrm{CPB}$.

Following redo sternotomy surgical hemostasis was obtained. Ten minutes prior to routine aortic and right atrial cannulation bivalirudin $110 \mathrm{mg}$ in (1.5 mg. $\mathrm{kg}^{-1}$ ) was administered as a bolus followed by an iv infusion of $2.5 \mathrm{mg} \cdot \mathrm{kg}^{-1} \cdot \mathrm{hr}^{-1}\left(180 \mathrm{mg} \cdot \mathrm{hr}^{-1}\right)$. A $50-\mathrm{mg}$ bolus of bivalirudin was added to the CPB circuit prime. Anticoagulation was monitored using a Medtronic II activated clotting time (ACT) device (Medtronic, Minneapolis, MN, USA) with kaolin based ACT (kACT) tubes and a Hemochron device for standard ACT and plasma modified ACT measurements. Activated clotting times were obtained at baseline, every ten minutes on $\mathrm{CPB}$ and post- $\mathrm{CPB}$ to attain a target kACT of $>400 \mathrm{sec}$. Five minutes after the first bivalirudin bolus the anticoagulated blood was sampled. This initial kACT level was $370 \mathrm{sec}$ and we administered an additional $20 \mathrm{mg}$ iv bolus of bivalirudin $\left(0.25 \mathrm{mg} \cdot \mathrm{kg}^{-1}\right)$ and increased the iv infusion by $0.25 \mathrm{mg} \cdot \mathrm{kg}^{-1} \cdot \mathrm{hr}^{-1}$ to $2.75 \mathrm{mg} \cdot \mathrm{kg}^{-1} \cdot \mathrm{hr}^{-1}$ (198 mg.hr' ${ }^{-1}$ ). This resulted in an acceptable pre-CPB kACT level of $440 \mathrm{sec}$. With adequate anticoagulation established, $\mathrm{CPB}$ was initiated in the usual fashion and conducted under mild hypothermia $\left(34.5{ }^{\circ} \mathrm{C}\right)$. To avoid blood stagnation in the bypass pump, the cardioplegia line was continuously flushed and blood suctioned from the surgical field was returned to a cell saver. 
TABLE I Alternative anticoagulants for cardiopulmonary bypass

\begin{tabular}{lll}
\hline Non-thrombin inbibitors \\
\hline & Danaparoid & Ancrod \\
$\mathrm{Tl} / 2$ elimination & $7-25 \mathrm{hr}$ & $3-5 \mathrm{hr},>24 \mathrm{hr}$ \\
Monitoring & Anti Xa levels & Fibrinogen \\
Reversal & Incomplete with protamine & $\mathrm{FFP}$, cryoprecipitate
\end{tabular}

Direct thrombin inbibitors

\begin{tabular}{llll}
\hline & r-hirudin & Argatroban & Bivalirudin \\
Thrombin binding & Irreversible & Reversible & Reversible \\
Metabolism & Renal & Hepatic & Plasma + renal \\
Tl/2 Elimination & $40-120$ min & $25-50$ min & 25 min \\
Monitoring & aPTT, ECT & aPTT, ACT & ECT, kACT \\
\hline
\end{tabular}

$\mathrm{FFP}=$ fresh frozen plasma aPTT $=$ activated partial thromboplastin time; $\mathrm{ECT}=$ ecarin clotting time; $\mathrm{ACT}=$ activated clotting time.

After opening the aorta the surgeons identified a large aortic root abscess extending under the left main coronary artery and onto the roof of the left atrium. The Toronto SPV aortic valve had multiple vegetations. A $23-\mathrm{mm}$ aortic root homograft was used to replace the damaged prosthetic valve and aortic root, and both coronary ostia were reimplanted. A saphenous vein graft was used to bypass the first obtuse marginal branch. The total CPB time was $121 \mathrm{~min}$ with an aortic cross clamp time of $100 \mathrm{~min}$.

The kACT values remained over $400 \mathrm{sec}$ during CPB without further adjustment of the bivalirudin infusion. There were no clots in the CPB system during the pump run, and pressures in the CPB lines remained normal. The only observation of blood clot was in the pericardial sac where blood stagnated. Ten minutes before discontinuation of CPB the bivalirudin infusion was stopped. The patient was weaned from CPB successfully on the first attempt with iv infusions of phenylephrine $\left(0.03 \mu \mathrm{g} \cdot \mathrm{kg}^{-1} \cdot \mathrm{min}^{-1}\right)$ and dopamine $\left(3 \mu \mathrm{g} \cdot \mathrm{kg}^{-1} \cdot \mathrm{min}^{-1}\right)$. Immediately post- $\mathrm{CPB}$ to prevent blood stagnation in the pump, the arterial and venous bypass lines were connected at the table. The perfusionist administered bivalirudin as a $50-\mathrm{mg}$ bolus and infusion of $50 \mathrm{mg} \cdot \mathrm{hr}^{-1}$ into the recirculating pump circuit. Eventually all the pump blood was processed through a cell saver using citrate, and reinfused into the patient. Despite an abnormal kACT, satisfactory hemostasis in the surgical field was obtained 30 to $40 \mathrm{~min}$ after terminating bypass and the pericardium and chest were closed without complication. The only blood products transfused intraoperatively were two units of fresh frozen plasma (FFP), 30 min post-CPB, for generalized oozing in the surgical field. The patient was transferred to the intensive care unit (ICU) without complications. Within the initial 24 hr postoperatively the patient lost $600 \mathrm{~mL}$ of blood, and received two units of packed red blood cells and two units of FFP. The patient had an ICU admission hemoglobin of $94 \mathrm{~g} \cdot \mathrm{L}^{-1}$ and an ICU discharge hemoglobin of $103 \mathrm{~g} \cdot \mathrm{L}^{-1}$. The patient was discharged from ICU on postoperative day (POD) one and from hospital on POD seven. A pre-discharge echocardiogram showed normal homograft valve function.

\section{Discussion}

This is one of the first reports describing the successful use of bivalirudin anticoagulation in a patient who underwent complex cardiac re-operation due to prosthetic valve endocarditis. This patient had extensive endocarditis with abscess, a previous sternotomy, and was at a high risk of perioperative bleeding and renal dysfunction. Bivalirudin was chosen because of its short half-time and clinical results ${ }^{3,6}$ showing less bleeding when compared to other heparin alternatives.

The optimal anticoagulation strategy for managing patients with HIT during cardiac surgery remains controversial. ${ }^{1,2,7}$ Heparin alternatives successfully used for CPB (Tables I and II) have included non-thrombin inhibitors (danaproid, ${ }^{8}$ ancrod ${ }^{9}$ ) and DTI (hirudin, ${ }^{10}$ argatroban, ${ }^{11}$ bivalirudin $) .{ }^{6}$ All three DTI drugs bind selectively to circulating and clot-bound thrombin and do not have an antidote. These drugs do not require anti-thrombin III as a cofactor, are not inactivated by PF4 and do not cross-react with heparin antibodies. The DTI drugs differ pharmacologically (Table I) and have been used successfully in the medical management of HIT-positive patients. ${ }^{1}$ Each DTI has been used off-label, with and without $\mathrm{CPB}$, during cardiac surgery. To use a DTI successfully for CPB, it must be safe, its effects must be easy to monitor, and the drug must have limited effect in the post-bypass period to avoid excessive bleeding.

Hirudin is a natural anti-thrombin now produced as recombinant ( $\mathrm{r}$ )-hirudin (lepirudin). The largest study reporting r-hirudin use during $\mathrm{CPB}$ described 57 patients, of whom 95\% were discharged uneventfully. ${ }^{10}$ The main disadvantages of $r$-hirudin include its potential to cause anaphylaxis and its dependence on renal clearance. There have been seven cases, including five fatal cases, of severe anaphylactic reactions to r-hirudin. ${ }^{2}$ Recombinant-hirudin use in patients with renal dysfunction makes the half-time unpredictable, and may result in excessive bleeding and massive blood transfusion. ${ }^{12}$

Experience with argatroban use for CPB is very limited. ${ }^{11,13,14}$ Several complications were reported includ- 
TABLE II Dosages of alternative anticoagulants for cardiopulmonary bypass

\begin{tabular}{|c|c|}
\hline Anticoagulants & Dosages for $C P B$ \\
\hline Danaparoid $^{8}$ & $\begin{array}{l}\text { Bolus } 125 \mathrm{U} \cdot \mathrm{kg}^{-1} \mathrm{iv} \text {, post-thoracotomy } \\
\mathrm{CPB} \text { prime } 3 \mathrm{U} \cdot \mathrm{mL}^{-1} \\
\text { Infusion } 7 \mathrm{U} \cdot \mathrm{kg}^{-1} \cdot \mathrm{hr}^{-1} \text { iv on } \mathrm{CPB} \\
\text { If clotting noted additional bolus } 1250 \mathrm{U} \\
\text { Stop infusion } 45 \mathrm{~min} \text { before end of CPB }\end{array}$ \\
\hline Ancrod $^{9}$ & $\begin{array}{l}\text { Infusion } 8.4 \mathrm{U} \cdot \mathrm{hr}^{-1} \times 12 \mathrm{hr} \text { preoperatively check } \\
\text { fibrinogen levels } \mathrm{q} 4 \mathrm{hr} \\
\text { Stop infusion preoperatively once the target } \\
\text { fibrinogen level of } 0.4 \text { to } 0.8 \mathrm{~g} \cdot \mathrm{L}^{-1} \text { is reached } \\
\text { If fibrinogen }>0.8 \mathrm{~g} \cdot \mathrm{L}^{-1} \text { restart the infusion at } \\
2.1 \mathrm{U} \cdot \mathrm{hr}^{-1}\end{array}$ \\
\hline Hirudin $^{10}$ & $\begin{array}{l}\text { Bolus } 0.25 \mathrm{mg} \cdot \mathrm{kg}^{-1} \text {, pre-cannulation } \\
\mathrm{CPB} \text { prime } 0.25 \mathrm{mg} \cdot \mathrm{kg}^{-1} \\
\text { Infusion } 0.5 \mathrm{mg} \cdot \mathrm{min}^{-1} \text { iv, maintain ECT }>400 \mathrm{sec} \\
\text { Additional bolus to maintain ECT } \\
\text { Stop infusion before end of CPB }\end{array}$ \\
\hline Argatroban ${ }^{11}$ & $\begin{array}{l}\text { Bolus } 0.1 \mathrm{mg} \cdot \mathrm{kg}^{-1} \mathrm{iv}, 20 \mathrm{~min} \text { pre-cannulation } \\
\text { Infusion } 5 \text { to } 10 \mu \mathrm{g} \cdot \mathrm{kg}^{-1} \cdot \mathrm{min}^{-1} \mathrm{iv} \text {, maintain ACT > } \\
400 \mathrm{sec} \\
\mathrm{CPB} \text { prime } 0.05 \mathrm{mg} \cdot \mathrm{kg}^{-1} \\
\text { Additional } 2 \mathrm{mg} \text { iv boluses to maintain ACT } \\
\text { Stop infusion before end of CPB }\end{array}$ \\
\hline Bivalirudin $^{6}$ & $\begin{array}{l}\text { Bolus } 1.5 \mathrm{mg} \cdot \mathrm{kg}^{-1} \text { iv, pre-cannulation } \\
\mathrm{CPB} \text { prime } 50 \mathrm{mg} \\
\text { Infusion } 2.5 \mathrm{mg} \cdot \mathrm{kg}^{-1} \cdot \mathrm{hr}^{-1} \mathrm{iv} \text {, maintain ECT > } \\
400 \mathrm{sec} \\
\text { Stop infusion before end of CPB }\end{array}$ \\
\hline
\end{tabular}

$\mathrm{CPB}=$ cardiopulmonary bypass $; \mathrm{ECT}=$ ecarin clotting time; $\mathrm{ACT}$ $=$ activated clotting time.

ing severe hemorrhage resistant to factor VIIa therapy ${ }^{13}$ and failure to achieve adequate anticoagulation during off-pump coronary artery bypass surgery $(\mathrm{CABG}) .{ }^{14}$

Bivalirudin has stable pharmacokinetics: its peak action occurs within five minutes of bolus injection, and the elimination half-life is $25 \mathrm{~min}$. Metabolism occurs by plasma proteolytic cleavage $(80 \%)$ and renal excretion $(20 \%)$, with prolonged action in dialysis dependent patients. Monitoring is done with ecarin clotting time (ECT), or kACT as the PT, PTT and thrombin time are all prolonged. There is no antidote and the drug has minimal side effects. ${ }^{3,6}$

Current experience with bivalirudin for $\mathrm{CPB}$ is based mainly on case-reports of HIT-positive patients who underwent $\mathrm{CABG},{ }^{15}$ heart transplantation, ${ }^{16}$ left ventricular assist implantation ${ }^{17}$ and pediatric heart surgery. ${ }^{18}$ There are small studies ${ }^{6,19}$ describing bivalirudin use in HIT-negative cardiac surgery patients who underwent elective on or off pump CABG surgery. Some report massive transfusion of blood products and the use of factor $\mathrm{VIIa}^{16}$ during the early postoperative period.
Appropriate monitoring of DTI effects remains an unresolved issue, especially since standard ACT has no linear correlation with DTI plasma concentration. ${ }^{17}$ The ECT more accurately detects inadequate DTI anticoagulation for CPB than the ACT. ${ }^{20}$ The ECT test is based on meizothrombin generation from prothrombin by ecarin. A DTI binds immediately to the permanently formed meizothrombin in a concentration-dependent fashion. Ecarin clotting time cannot be used to detect disturbed coagulation, but is highly specific for therapeutic monitoring of antithrombin activity. ${ }^{21}$

In the absence of ECT monitoring, $\mathrm{kACT}$ and plasma modified ACT can be used. Koster et al. ${ }^{22}$ showed a $60 \%$ improved accuracy of monitoring unfractionated heparin levels post bypass with modification of the standard ACT assay. In this modified assay, a sample of platelet poor plasma is added in a oneto-one dilution to whole blood measured with the standard ACT tube. Jabr et al. ${ }^{23}$ used plasma modified ACT to track bivalirudin effect during CPB and obtained reasonable correlation with standard ACT. Similar to other reports, ${ }^{20,24}$ our comparison showed differences between standard ACT, kACT and plasma modified ACT. The tendency to increase or decrease was consistent in all three measurements. The values of plasma modified ACT were lower when compared to standard ACT or kACT.

Re-establishing hemostasis after CPB relies upon meticulous surgical technique and a decreasing bivalirudin drug effect, since there is no antidote. Case reports, including ours, suggest despite laboratory abnormalities, adequate clinical hemostasis occurs within 30 to 40 min post bypass. Blood product (FFP, platelets) administration should be guided by clinical circumstances beyond 30-min post bypass. Elimination of bivalirudin can be facilitated with the use of modified, zero-balanced ultra filtration. ${ }^{6}$ Aprotinin can be used to minimize post bypass bleeding. ${ }^{10}$

Bivalirudin offers one more theoretical advantage when used for patients receiving coronary artery grafts, as our patient did. Merry et al. ${ }^{19}$ compared 50 patients who had off-pump CABG with heparin vs 50 patients who had the same procedure, using bivalirudin. Graft patency and flow was better in the bivalirudin group. These results are noteworthy, and raised a question as to whether bivalirudin anticoagulation really improved graft patency. This may be possible, because thrombin has mitogenic properties and bivalirudin as a DTI can slow down or inhibit endothelial proliferation, and protect newly sutured grafts.

Our experience with bivalirudin for anticoagulation during $\mathrm{CPB}$ in this patient with HIT and endocarditis 
was highly favourable. This patient had none of the complications reported with the use of alternative anticoagulants for $\mathrm{CPB}$, which included excessive bleeding during the post-bypass period, or thrombosis within the extracorporeal circulation. We did not have problems achieving adequate anticoagulation before $\mathrm{CPB}$ or monitoring with $\mathrm{kACT}$ during $\mathrm{CPB}$. This case report suggests that bivalirudin is a viable alternative anticoagulant in a HIT-positive patient during CPB for complex redo cardiac surgery.

\section{References}

1 Warkentin TE, Greinacher A. Heparin-induced thrombocytopenia: recognition, treatment, and prevention. The seventh AACP conference on antithrombotic and thrombolytic therapy. Chest 2004; 126: 311S-37S.

2 Gurbuz AT, Elliot WG, Zia AA. Heparin-induced thrombocytopenia in the cardiovascular patient: diagnostic and treatment guidelines. Eur J Cardiothorac Surg 2005; 27: 138-49.

3 Sciulli TM, Mauro VF. Pharmacology and clinical use of bivalirudin. Ann Pharmacother 2002; 36: 1028-41.

4 Davis Z, Anderson R, Short D, Garber D, Valgiusti A. Favorable outcome with bivalirudin anticoagulation during cardiopulmonary bypass. Ann Thorac Surg 2003; 75: 264-5.

5 Bott JN, Reddy K, Krick S. Bivalrudin use in off-pump myocardial revascularization in patients with heparininduced thrombocytopenia. Ann Thorac Surg 2003; 76: 273-5.

6 Koster A, Spiess B, Chew DP, et al. Effectiveness of bivalirudin as a replacement for heparin during cardiopulmonary bypass in patients undergoing coronary artery bypass grafting. Am J Cardiol 2004; 93: 356-9.

7 Matthai WH Jr. Thrombocytopenia in cardiovascular patients. Diagnosis and management. Chest 2005; 127 : 46S-52S.

8 Magnani HN, Beijering RJ, Ten Cate JW, Chong BH. Orgaran anticoagulation for cardiopulmonary bypass in patients with heparin-induced thrombocytopenia. In: Pifarre R (Ed.). New Anticoagulants for the Cardiovascular Patient. Philadelphia: Hanley \& Belfus Inc.; 1997: 487-500.

9 Zulys VJ, Teasdale SJ, Michel ER, et al. Ancrod (Arvin $\AA$ ) as an alternative to heparin anticoagulation for cardiopulmonary bypass. Anesthesiology 1989; 71: 870-7.

10 Koster A, Hansen R, Kuppe H, Hetzer R, Crystal GJ, Mertzlufft $F$. Recombinant hirudin as an alternative for anticoagulation during cardiopulmonary bypass in patients with heparin-induced thrombocytopenia type II: a 1-year experience in 57 patients. J Cardiothorac Vasc Anesth 2000; 14: 243-8.
11 Edwards JT, Hamby JK, Worrall NK. Successful use of argatroban as a heparin substitute during cardiopulmonary bypass: heparin-induced thrombocytopenia in a high-risk cardiac surgical patient. Ann Thorac Surg 2003; 75: 1622-4.

12 Nuttall GA, Oliver WC Jr, Santrach PJ, et al. Patients with a history of type II heparin-induced thrombocytopenia with thrombosis requiring cardiac surgery with cardiopulmonary bypass: a prospective observational case series. Anesth Analg 2003; 96: 344-50.

13 Malherbe S, Tsui BC, Stobart K, Koller J. Argatroban as anticoagulant in cardiopulmonary bypass in an infant and attempted reversal with recombinant activated factor VII. Anesthesiology 2004; 100: 443-5.

14 Cannon MA, Butterworth J, Riley RD, Hyland JM. Failure of argatroban anticoagulation during off-pump coronary artery bypass surgery. Ann Thorac Surg 2004; 77: $711-3$.

15 Clayton SB, Acsell JR, Crumbley III AJ, Shackelford $A G$, Uber WE. Cardiopulmonary bypass with bivalirudin in type II heparin-induced thrombocytopenia. Ann Thorac Surg 2004; 78: 2167-9.

16 Stratmann G, deSilva AM, Tseng EE, et al. Reversal of direct thrombin inhibition after cardiopulmonary bypass in a patient with heparin-induced thrombocytopenia. Anesth Analg 2004; 98: 1635-9.

17 Welsby IJ, Stafford-Smith M. Monitoring direct thrombin inhibitors: time for standardization (Letter). Anesthesiology 2004; 101: 1048-9.

18 Klenner AF, Lubenow N, Raschke R, Greinacher A. Heparin-induced thrombocytopenia in children: 12 new cases and review of the literature. Thromb Haemost 2004; 91: 719-24.

19 Merry AF, Raudkivi PJ, Middleton NG, et al. Bivalirudin versus heparin and protamine in off-pump coronary artery bypass surgery. Ann Thorac Surg 2004; 77: 925-31.

20 Koster A, Chew D, Grundel M, Bauer M, Kuppe H, Spiess BD. Bivalirudin monitored with ecarin clotting time for anticoagulation during cardiopulmonary bypass. Anesth Analg 2003; 96: 383-6.

21 Lange U, Nowak G, Bucha E. Ecarin chromogenic assay - a new method for quantitative determination of direct thrombin inhibitors like hirudin. Pathophysiol Haemost Thromb 2003; 33: 184-91.

22 Koster A, Despotis G, Gruendel M, et al. The plasma supplemented modified activated clotting time for monitoring of heparinization during cardiopulmonary bypass: a pilot investigation. Anesth Analg 2002; 95 : 26-30.

23 Jabr K, Johnson JH, McDonald MH, et al. Plasma modified ACT can be used to monitor bivalirudin (Angiomax ${ }^{\circledR}$ ) anticoagulation for on-pump cardio- 
pulmonary bypass surgery in a patient with heparininduced thrombocytopenia. J Extra Corpor Technol 2004; 36: 174-7.

24 Despotis GJ, Hogue CW, Saleem R, et al. The relationship between hirudin and activated clotting time: implications for patients with heparin-induced thrombocytopenia undergoing cardiac surgery. Anesth Analg 2001; 93: 28-32. 